\title{
A LONG-TERM VISION FOR UK FIRMS? REVISITING THE TARGET DIRECTOR'S ADVISORY ROLE SINCE THE TAKEOVER OF CADBURY'S PLC
}

\author{
GEORGINA TSAGAS*
}

\begin{abstract}
The takeover of Cadbury by Kraft in 2010 led to the questioning of the UK's open market for corporate control and initiated a political enquiry into the framework regulating takeover bids. One of the concerns brought forward is that, contrary to their role, target directors act more like "auctioneers" selling to the highest bidder rather than "stewards" looking after the company's long-term interests. The target board's role as an advisor will be analysed with reference to the City Code on Takeovers and Mergers, common law, the Companies Act 2006 and the EU Takeover Directive. It will be argued that the grey areas of law reported on are the result of the conflicting aims to facilitate an open market for corporate control, whilst sustaining companies with a long-term vision. The legal solution proposed is strengthening the target board's advisory role by providing directors with guidelines on how to construct their recommendation of a bid to shareholders.
\end{abstract}

\section{A. InTroduction}

In terms of financial welfare, hostile takeovers possess a specific positive rationale of replacing a less productive management with a more competent one. ${ }^{1}$ The British economy is predominantly based on the efficiency of its companies and has provided for rules that favour the success of such acquisitions. ${ }^{2}$ The non-frustration rule of the City Code on Takeovers and Mergers (the Code) prohibits

\footnotetext{
${ }^{1}$ H Manne, "Mergers and the Market for Corporate Control" (1965) 73 Journal of Political Economy 73; J Parkinson, Corporate Power and Responsibility: Issues in the Theory of Company Law (Clarendon Press 1993) 156.
}

${ }^{2}$ B Butcher, Director's Duties: A New Millennium, A New Approach (Kluwer Law International 2000) 6. 
directors from using any sort of defence mechanism to block an acquisition, once a bid is imminent, without fi rst obtaining share-

* Postdoctoral Research Associate in Corporate Law, Faculty of Laws, University College London. I would like to thank Professor David Millon, Professor Edward Walker-Arnott and Professor Rosa Lastra for helpful suggestions and constructive comments. I would also like to thank the anonymous reviewer for his constructive comments that greatly contributed to improving the final version of the paper.

holder approval. ${ }^{3}$ The rules have been tailored in such a way as to render managers mere advisers, leaving the ultimate decision to shareholders. In assuming their advisory role. target directors continue to owe fiduciary duties towards the company as a whole and are held liable for the advice they give to shareholders. ${ }^{4}$ Despite the takeover-related restrictions imposed on directors' standard authority, target directors hold an indirect power to defend against an unwanted bid by using their recommendation to possibly steer target shareholders in one direction or another. ${ }^{5}$ Directors' influence does not merit value only in theory; empirical studies have shown that target board recommendations "are the most important variable in determining takeover outcomes". 6

Even though directors' influence on takeover outcomes has been established, the role that target directors are called to play during a takeover bid remains an ambiguous one. Tuch identifies the challenges that confront the parties involved in a takeover by analysing a hypothetical takeover case and reaches the conclusion

${ }^{3}$ The City Code on Takeovers and Mergers (the Code), $\mathrm{r} 21$.

${ }^{4}$ L Rybak, "Takeover Regulation and Inclusive Corporate Governance: A Social-Choice Theoretical Analysis" (2010) 10(2) Journal of Corporate Law Studies 407, 412.

${ }^{5}$ See B Clarke, "Corporate Governance Regulation and Board Decision Making" in T Gopinath Arun and J Turner (eds), Corporate Governance and Development-Reform Financial Systems and Legal Frameworks (Edward Elgar Publishing 2009) 131; see also P Davies and K Hopt, "Control Transactions" in RH Kraakman et al (eds), The Anatomy of Corporate Law: A Comparative and Functional Approach (2nd edn, OUP 2009) 235.

${ }^{6}$ B Clarke "Reinforcing the Market for Corporate Control" (2010) UCD Working Papers in Law, Criminology \& Socio-Legal Studies Research Paper No 39/2010, 11_<http://ssrn.com/ abstract $=1661620>$ accessed 1 January 2014. 


\section{FORTHECOMING}

that target directors in specific are faced with a difficult task because of the complex legal principles to which they are subject, the application of which is uncertain. ${ }^{7}$ Arguably, the role of the target board is straightforward, in that its task is simply a matter of providing shareholders with an "informed assessment of the financial merits of a bid" and nothing more. ${ }^{8}$ However, recent UK market failures and reported incidents of short-termism since autumn 2008 have led policy-makers to rethink the legal framework in existence and pose the question of whether "boards consider sufficiently carefully the long-term implications of takeover bids, and whether they communicate these effectively to shareholders and wider stakeholders". 9

This paper will begin by introducing the background to the reform of the UK takeover rules which preceded the successful takeover of Cadbury by Kraft in 2010. Next, it will refer to the facts of the takeover of Cadbury plc, with a particular focus on the advice given by the target board to the Cadbury shareholders. Using the takeover of Cadbury plc as a paradigm, the regulatory framework in relation to target board recommendations will be outlined. Reference will be made to the Code, common law, the Companies Act 2006 and the EU Takeover Directive. The hypothesis of the paper is that the grey areas of law discussed are the result of the conflicting aims: on the one hand, to facilitate an open market for corporate control, and on the other, to promote the long-term continuity of UK fi rms. As market efficiency is being questioned and as the motives behind takeover attempts may vary, the complementary function of the target board's advice in addressing problematic aspects identified in the operation of an open market for corporate control will be highlighted. It will be argued that the type of offer made, whether this is a paper or cash consideration for shares in the target, as well

\footnotetext{
${ }^{7}$ See A Tuch, "Contemporary Challenges in Takeovers: Avoiding Conflicts, Preserving Confidences and Taming the Commercial Imperative" (2006) 24 Company \& Securities Law Journal 107.

${ }^{8}$ Rybak (n 4) 412.

${ }^{9}$ Department for Business Innovation and Skills, Consultation Document, "A Long-Term Focus for Corporate Britain-A Call for Evidence (2010) URN 10/1225, 4-5 and 33 (Consultation Document BIS).
} 
as the identity of target shareholder and their investor horizon, are important variables that have been overlooked by the law and past research. The arguments provided suggest that there is a need for the regulator to address directors' duties within the takeover context specifically and set out provisions in the Code or the Companies Act accordingly.

\section{B. THE TAKEOVER OF CADBURY PLC AS A DRIVER OF REFORM}

The call for reform of the UK takeover rules was set off by the successful takeover of Cadbury by Kraft in 2010. The political backdrop to the takeover of Cadbury by Kraft had Lord Mandelson, the Secretary of State for Business, Innovation, and Skills in 2010, proclaim the need for reform of UK rules on takeover bids and directors' duties in order to promote long term engagement and ownership amongst shareholders and boards. ${ }^{10}$ The ease by which UK companies with so-called short-term investors, such as hedge funds, can be taken over was but one of the focal points of the debate. The same takeover also highlighted the fact that, contrary to their role as prescribed in General Principle 3 of the Code "to act in the interest of the company as a whole", target directors tend to act more like auctioneers, selling to the highest bidder by recommending any price that significantly exceeds the company's trading price, rather than stewards, looking after their company's long-term interests and considering the long-term implications of the takeover bid in their advice. ${ }^{11}$ Lord Mandelson highlighted the ambiguous role that directors are required to perform during the fast-moving circumstances of a takeover when those who have recently invested

10 Lord Mandelson, speech at Manor House, London, 1 March 2010 <http://www.totalpolitics.com/speeches/economics/economic-policy/35208/lord-mandelsonmansion-house-speech. thtml> accessed 1 January 2014.

${ }^{11} \mathrm{~T}$ Webb, "Lord Mandelson Calls for Overhaul of Takeover Rules" The Guardian (1 March 2010); see also Code Committee of the Takeover Panel, "Response Statement to the Consultation Paper on Review of Certain Aspects of the Regulation of Takeover Bids" (21 October 2010) RS 2010/22 (First Response Paper) ss 2.5, 3 <http://www.thetakeoverpanel.org.uk/ wpcontent/uploads/2009/12/2010-221.pdf> accessed 1 January 2014. 
in the company do not have a long-term commitment to it. ${ }^{12} \mathrm{He}$ thus proposed restating the 2006 Companies Act directors' duties if necessary, and added that the UK Stewardship Code should make clear that fund managers and ultimate owners adopt a long-term commitment towards investment. ${ }^{13}$

Following this, the Department for Business Innovation and Skills issued a consultation document entitled "A Long-term Focus for Corporate Britain-A Call for Evidence" in October 2010 with the aim of understanding whether and to what extent the UK system fosters - or undermines - the long-term growth of corporations. ${ }^{13}$ In the report, a section was devoted to the role of the board, investor engagement and the economic case for takeovers. ${ }^{14}$ A summary of responses to the consultation was published in March 2011. ${ }^{15}$ The consultation had sought to specifically explore whether UK boards have a long-term focus and, if not, the reasons that lie behind this. To this question, the majority of respondents were of the view that boards did in fact have a long-term vision for the firm, but have to deal with increasing short-term pressures from investors, analysts and the markets. ${ }^{16}$ It was also mentioned that the divide between short-term and long-term was an ambiguous one, and that the terms may well vary depending on the sector or the company in question. ${ }^{18}$ To the question of whether boards understand the long-term implications of takeovers, and whether they communicate the longterm implications of bids effectively to target shareholders,

\footnotetext{
${ }^{12}$ Lord Mandelson speech (n 10).

13 ibid.

${ }^{13}$ See Consultation Document BIS (n 9) 33.

14 ibid 8.

${ }^{15}$ Department for Business, Innovation and Skills, Summary of Responses Document, "Summary of Reponses, A Long-term Focus for Corporate Britain" (2011) URN 11/797_ <www.bis.gov. uk/assets/biscore/business-law/docs/s/11-797-summary-responses-long-term-focuscorporatebritain.pdf> accessed 1 January 2014 (Summary of Responses Document BIS); see also Department for Business, Innovation and Skills, Briefing on Consultation <www.bis.gov.uk/ Consultations/a-long-term-focus-for-corporate-britain> accessed 1 January 2014, where it is reported that, following the responses to the call for evidence which identified a number of issues with short-termism, the Secretary of State commissioned an independent review to examine investment in UK equity markets and its impact on the long-term performance and governance of UK quoted companies to Professor J Kay.

${ }^{16}$ Summary of Responses Document BIS (n 16) 7.

18 ibid.
} 
respondents' responses were mixed. ${ }^{17}$ A key observation made was that target boards face difficulties in not recommending an offer to shareholders when the offer price is high, as they find it difficult to explain why such a bid should not be accepted. ${ }^{18}$ Another observation made by a few respondents was that the information target directors provide to shareholders is too backward-looking, as it focuses solely on historical information on the company's past performance. ${ }^{19}$ Certain respondents recommended that the Takeover Code should be better linked to section 172 of the Companies Act 2006 with regard to directors duties, although on this point other responses questioned whether that section would be effective in guiding the decision-making process amidst a takeover, and recommended a further study of its efficacy in this context. ${ }^{20} \mathrm{~A}$ number of respondents supported the disclosure of the long-term implications of a bid and the enactment of provisions introducing more due diligence. ${ }^{23}$ Following the responses to the call for evidence which identified a number of issues with short-termism, the Secretary of State commissioned an independent review to examine investment in UK equity markets and its impact on the long-term performance and governance of UK-quoted companies to Professor J Kay, who produced his review in February 2012. ${ }^{21}$

As a matter of political enquiry, the UK Takeover Panel (the Panel) was prompted to review certain aspects of the regulation on takeover bids. For this purpose, the Panel set up a special Code Committee, which issued a public consultation paper (PCP 2010/22), published in June 2010. Suggestions to amend the

\footnotetext{
17 ibid 21.

18 ibid 21.

19 ibid 22.

${ }^{20}$ ibid 22. ${ }^{23}$
}

bid 22.

${ }^{21} \mathrm{~J}$ Kay, The Kay Review of UK Equity Markets and Long-Term Decision Making: Interim Report (February 2012) 14. The review reflected on the problems linked to the Cadbury experience, addressing, among others, the means via which companies can be prompted to achieve long-term success. The proposals made were providing more discretion for directors to reject unsuitable bids, the possibility of review of takeovers by a public agency, differential rights for shareholders and lowering for the bidder or raising for the target the threshold at which shareholder approval of a bid is required. 
takeover rules included, but were not limited to, issues such as raising the " $50 \%$ plus one" minimum acceptance condition threshold to 60 per cent, withholding voting rights from shares in the target company acquired during the course of an offer period and requiring bidders to provide more information in relation to the financing of the takeover bid and its implications and effects. ${ }^{22}$ In the paper, the Committee considered, amongst other things, whether it was essential that the Code outline the factors that the target board should take into consideration in its decision to recommend a bid. ${ }^{23}$ The motion of outlining these factors in the Code by amending its current provisions failed, as the majority of the Committee considered that the takeover rules should not be too prescriptive in defining the variables that the offeree board needs to take into account when recommending a bid. ${ }^{27}$ However, the Panel did recognise that market participants are under the misconception that the determining factor when considering whether to recommend a bid or not is the offer price. It thus committed itself to making amendments so as to clarify that the Code does not limit the factors which can be taken into account by the target board and that the offer price is not the determining factor when doing so. ${ }^{24}$

Following the Panel's consultation document, a new section has been added to the revised 10th edition of the Code in the notes following rule 25.2, which makes it clear that, when giving its opinion of a bid, the target board "is not required by the Code to consider the offer price as the determining factor and is not precluded by the Code from taking into account any other factors which it considers relevant". ${ }^{25}$

The Panel has now made it clear that target directors need not provide advice that is merely focused on the financial merits of the

\footnotetext{
${ }^{22}$ Code Committee of the Takeover Panel, "Consultation Paper, Review of Certain Aspects of the Regulation of Takeover Bids" (1 June 2010) PCP 2010/2 (First Consultation Paper) 5-6, s 1.17 <http://www.thetakeoverpanel.org.uk/wp-content/uploads/2008/11/PCP201002.pdf > accessed 1 January 2014.

${ }^{23}$ First Response Paper (n 11), 16, point (ii), s 5.2.1.

27 ibid.

${ }^{24}$ ibid 16, point (ii), s 5.2.2.

${ }^{25}$ The Code, notes on r 25.2, point 1 .
} 
bid. However, the Committee's reluctance to outline the other factors the board could take into account when deciding on its recommendation retains the problem that exists in the current legal framework, namely target directors' ambiguous advisory role. The Committee has arguably attached more controversy to the topic than existed before, as it has officially broadened the range of factors which can be taken into account without identifying them specifically. Using the successful takeover of Cadbury plc as a paradigm, the following section will refer to the facts of the case and make specific reference to the recommendation given by the target board of directors to Cadbury's shareholders. It will explore the reasons that lay behind the target board's initial reluctance to recommend the bid made by Kraft as opposed to recommending the bid only a few days later.

\section{CASE STUDY: THE CADBURY PLC TAKEOVER BY KRAFT FOODS INC}

Kraft's final offer to acquire Cadbury at a price of $£ 11.9$ billion on 19 January 2010, supported by the Cadbury board's recommendation, marked the beginning of a successfully completed takeover. The Cadbury plc board of directors had twice turned down Kraft's offers, before finally deciding to recommend Kraft's bid. ${ }^{26}$ The target board's sudden change of heart caused fury among the British community, as it was only within a few days of Kraft's offer of a higher price for Cadbury's shares that the target board altered its advice entirely and finally recommended the bid to its shareholders. Roger Carr, former chairman of Cadbury plc, claimed that the board was left with no choice but to recommend the bid in light of the fact that the type of shareholders deciding on the future of the company tended to prefer a short-term gain over longer-term 
wealth. ${ }^{27} \mathrm{He}$ continued by stating that, under such circumstances, recommending the bid was clearly a matter of achieving a high price for the value of the company rather than considering its independent future and long-term continuity. ${ }^{32}$

Initially, when Kraft first made a cash-and-shares offer to purchase the entire stock of Cadbury in September 2009 at a price of $£ 10.2$ billion, the Cadbury board of directors had insisted on the offer being rejected as it "fundamentally" undervalued the company. ${ }^{28}$ On 14 January 2010, only a few days before recommending the bid, the board of directors of Cadbury plc had issued a second statement towards its shareholders urging them once again not to accept any offer made by Kraft Foods Inc on the basis that Kraft's offer substantially undervalued Cadbury. This was supported by independent financial advice the board had received from its advisers. ${ }^{29}$ However, it is important to point out that rejection of the offer was not advised solely on the grounds of the low share price offered. The statement of the target board to shareholders built up a case in favour of the continuity of Cadbury as an independent company. The board maintained that Cadbury would be committed to shareholder value, portraying that the company had delivered outstanding performance in 2009 amidst the financial crisis and that this performance would provide the foundation for the realisation of the company's long-term goals. ${ }^{30}$ At the same time, the statement contained data focusing on Kraft's weak past performance, its exposure to lower growth categories and its past failure to meet financial targets. ${ }^{31}$ However, in just a few days, the Cadbury board shifted from rejecting the bid on a series of

\footnotetext{
${ }^{27}$ R Carr, "Cadbury: Hostile Bids and Takeover", speech at Saïd Business School, Oxford (15 February 2010)

〈http://www.sbs.ox.ac.uk/newsandevents/previousevents/Pages/RogerCarrCadbury.aspx> accessed 1 January 2014.

32 ibid.

28 "Confectionary; Hovering Kraft" The Economist (7 September 2009).

${ }^{29}$ Cadbury's Board Statement, “Second Response Document to Cadbury's investors" (14 January 2010) 3 .

30 ibid 2.

${ }^{31}$ ibid 18.
} 
grounds to recommending the bid solely on the grounds that Kraft had offered a higher price for the company's shares.

The target board's final say was in fact a reflection of what the socalled short-term shareholders within the target company considered to be beneficial and in line with shareholders' own corporate strategy of capitalising on their investment in the short term. Socalled long-term investors had begun disposing of their investment in the company in 2006. It was reported that a salmonella scare in 2006 had led to a widespread recall of Cadbury's products in Britain and by 2008 share prices had fallen, with most of the big institutional investors having withdrawn their investment. ${ }^{32}$ In July 2008, though, the CEO of Cadbury, Sir John Sunderland, was replaced by Roger Carr, who immediately set out a plan of improving Cadbury's financial performance by 2011 through pushing management to meet new financial goals and through extensive restructuring of the company's assets and human capital. ${ }^{33}$ Progressively, however, by September 2009, when the bid by Kraft was being launched, UK investors ended up holding a smaller stake in the company than North American investors. ${ }^{34}$ As the share prices of Cadbury started to rise, when Kraft was first signalling its interest, ownership patterns changed with North American investors pulling out and with hedge fund investments rising from a 5 per cent to a 31 per cent holding in the company. ${ }^{40}$ The outcome of the bid was thus argued to be dependant upon the bidder, ie Kraft Foods Inc offering the right price to such short-term investors. Despite Cadbury's business having started to improve in the beginning of 2008, investors who had been let down by the former board of directors in the past were reluctant to hold on to their

stock once the bid for the company was made in $2009 .{ }^{35}$

\footnotetext{
32 "Foreign Takeovers in Britain: Small Island for Sale" The Economist (25 March 2010).

${ }^{33}$ J Wiggins "The inside story of Cadbury Takeover" The Financial Times (12 March 2010).

34 "Foreign Takeovers in Britain" (n 37).

40 ibid.

${ }^{35}$ Wiggins (n 38).

42 ibid.
} 
In the aftermath of the acquisition, a valid point to be made would be that the market for corporate control had operated effectively insofar as so-called long-term investors had previously disposed of their shares, indicating their dissatisfaction with the way in which Cadbury was being formerly managed. ${ }^{42}$ However, to determine whether the market for corporate control had functioned correctly in replacing a less efficient management team with a more competent one, we also to need consider Kraft's ability to run the company's business, as well as the motives that lay behind Kraft's acquiring Cadbury. In terms of efficient management, Kraft had, prior to the acquisition, been criticized by the target board for being an unfocused conglomerate with lower exposure to fast-growing emerging markets, exposure to unappealing categories and underperformance overall. ${ }^{36}$ Reports on Kraft's performance in 2007 also found that Kraft was underperforming its food company competitors in recent years, due to the fact that the company had failed to follow up on what had previously made it successful, namely new products, innovation and world-class marketing. ${ }^{37} \mathrm{It}$ was estimated that, if Kraft did not alter its strategy, its prospective future growth would only be temporary and unsustainable. ${ }^{45}$ In terms of the motives that lay behind the acquisition, Kraft's intention of administering the company's business more efficiently than the Cadbury board had previously done was perhaps only one of its intentions. Kraft's main motive for launching a takeover on Cadbury was in fact Kraft's plan to expand its confectionary industry in the British market, where Cadbury was already well established, and in the chewing gum business in Europe and Latin America, where Cadbury's presence was strong. ${ }^{38}$ Kraft's intention was also to compete with the newly merged Mars/Wrigley company, created in $2008 .^{47}$

\footnotetext{
${ }^{36}$ See Cadbury Board Statement (n 34) 14-17.

${ }^{37}$ Gerson Lehrman Group Inc, "Where's Kraft Foods Volume Growth?” (14 September 2007) <http://www.glgroup.com/News/Wheres-Kraft-Foods-Volume-Growth---16669.html> accessed on 1 January 2014.

ibid.

38 "Confectionary; Hovering Kraft" (n 33).

47 ibid.
} 
It will be argued that the target directors' ambiguous stance towards the Kraft deal may be consistent with the fact that the legal framework fails to direct target boards on how to observe their role and construct their recommendations. The following section will provide an outline of the provisions of the Code, common law, the Companies Act 2006 and the Takeover Directive, and demonstrate the grey areas of law. The legal gaps reported on are arguably at the core of the problem identified in the Kraft deal and have not been sufficiently dealt with by regulators recently considering takeover law reform in the UK.

\section{THE PROBLEMATIC LEGAL FRAMEWORK: THE "LEGAL CERTAINTY" ARGUMENT}

In a takeover context, directors are subject to a combination of common law, statutory rules and self-regulation. ${ }^{39}$ An outline of directors' legal obligations as advisors according to the Code, common law and the Companies Act 2006 will make clear that the board and those affected by their actions do not have a clear notion of their role and, in particular, which factors need be considered by the board when recommending a bid. Defining the target directors' advisory role within a takeover context, however, may help facilitate legal certainty.

\section{The Code}

In discussing the target director's role as an advisor, it is important to begin by referring to the Code's purpose. The Code essentially aims to ensure that the shareholders in an offeree company are treated fairly and are not denied an opportunity to decide on the merits of a bid. ${ }^{40}$ The board's aim is to ensure that shareholders have

\footnotetext{
${ }^{39}$ See Lord Hoffman, "Directors' Duties" in M Andenas and D Sugarman (eds), Developments in European Company Law, Volume 3, 1999. Director's Conflicts of Interest: Legal, Socio-Legal and Economic Analyses (Kluwer International Law 2000).

${ }^{40}$ The Code, Introduction and General Principle 2.
} 
been sufficiently informed about the merits of the offer and to overall supervise the conduct of the parties participating in the takeover process. ${ }^{41}$ The Code is not concerned with the financial or commercial advantages or disadvantages of a takeover, which are matters left to the offeree company and its shareholders. ${ }^{42}$

Shareholders of the offeree company are thus provided with information on the terms of the offer as such, with information about the target and the bidding companies, as well as with the target board's opinion on the merits of the proposed bid. ${ }^{43}$ Rule 23 points out that shareholders must be given sufficient information and advice to be able to reach an informed decision on the merits of a bid, and no relevant information should be withheld form them. According to rule 24.2, the offer document must contain, amongst others, information on the bidder's intentions regarding the offeree company, the offeror company and their employees. In particular, the bidding company must state its intentions with regard to the future business of the offeree company and explain the long-term commercial justification of the offer. ${ }^{44}$ It must also state, amongst other things, its intentions with regard to the continued employment of the employees and management of the offeree company, its strategic plans for the offeree company, and their likely repercussions on employment and the locations of the offeree company's business. ${ }^{45}$ According to rule 24.2(b), where the offeror is a company, it must also provide information with regard to its own future business.

The Code imposes a series of positive obligations on target directors. ${ }^{46}$ Their central role in offsetting and coordinating the

\footnotetext{
${ }^{41}$ The Code, Introduction and para 1, app 3, s 1.

${ }^{42}$ The Code (10th edn), Introduction.

${ }^{43}$ D Kershaw, "Web Chapter A: The Market for Corporate Control" in D Kershaw, Company Law in Context: Text and Materials (OUP 2010) 65-66.

${ }^{44}$ The Code, r 24.2 (a).

${ }^{45}$ The Code, r 24.2(a)(i) (ii) (ii) and (iv).

${ }^{46}$ See the Code, General Principles 2, 3, 6, r 3.2, r 25.1, app 3, r 2.3, r 2.4, r 2.6, r 3.1, r 21 and app 2.3(9).
} 
process is clearly specified in a number of provisions. ${ }^{47}$ The common law duty to act in the interests of the company is extended through General Principle 3, which states that "The board of an offeree company must act in the interests of the company as a whole and must not deny the holders of securities the opportunity to decide on the merits of the bid".

Rule 25.1 specifies that directors are under the obligation to circulate their opinion on the offer, including any alternative offers, to target shareholders, parallel to providing them with the independent advice obtained pursuant to rule 3.1. ${ }^{48} \mathrm{In}$ its opinion of the bid, the board must also give its views on the effects of proposed bid on employment and its conditions, as well as the locations of the company's places of business. ${ }^{49}$ Rule 25.2 in specific stipulates that the board should mention the reasons for forming its opinion, and must specifically include its views on:

(i) the effects of implementation of the offer on all the company's interests, including, specifically, employment; and (ii) the offeror's strategic plans for the offeree company and their likely repercussions on employment and the locations of the offeree company's places of business, as set out in the offer document pursuant to rule $24.2 .^{50}$

Of particular importance for the purposes of our discussion are the notes on rule 25.2(b), a new section introduced by the 10th edition of the Code dated 19 September 2011, which make reference to the factors which the target board can take into consideration by stating that:

The provisions of the Code do not limit the factors that the board of the offeree company may take into account in giving its opinion

\footnotetext{
${ }^{47}$ See the Code, r 2.3, s (c), r 2.4, ss (a) and (b), and r 2.12; see also the Code, r 2.3(c). Note that rr 2.3 and 2.4 in specific require that following an approach to the board of the offeree company, the offeree company is responsible for making any announcement required under $\mathrm{r} 2.2$ and that the announcement by the offeree company which commences an offer period must identify any potential offeror with which the offeree company is in discussions with.

${ }^{48}$ The Code, r 25.2(b).

${ }^{49}$ The Code, General Principle 2.

${ }^{50}$ The Code, s J18.
} 
on the offer in accordance with rule 25.2(a). In particular, when giving its opinion, the board of the offeree company is not required by the Code to consider the offer price as the determining factor and is not precluded by the Code from taking into account any other factors which it considers relevant. ${ }^{51}$

In its response, the board of the offeree company must also take into consideration the advice which has been provided by the independent adviser, who will have assessed the trading history of the target's share prices. ${ }^{52}$ Rule 19.2 specifies that any document issued by the bidder or target must be accompanied by a statement that the directors accept responsibility for the information contained in it. 53

The rules set out in the Code have a statutory basis since the implementation of the EU Takeover Directive ${ }^{54}$ and, as the Code points out, it does in fact impose obligations and limitations on company directors through its provisions that may impinge on the duties that the directors of the target and bidding companies might normally owe. ${ }^{64}$ It does not, however, clarify the extent to which these duties overlap, which, as will be made evident, can create confusion, as well as inconsistency, in the legal world. The following section will refer to the target directors' advisory role through the prism of relevant common law cases.

\section{Common Law}

At common law and within a takeover context, the courts have attempted to define the limits of directors' duties by referring

\footnotetext{
${ }^{51}$ The Code, note 1 to $\mathrm{r} 25.2$.

${ }^{52}$ See the Code, $\mathrm{r} 3.1$, which requires the board of the offeree company to obtain competent independent financial advice on any offer.

${ }^{53}$ S Deakin and G Slinger, "Hostile Takeovers, Corporate Law and Theory of the Firm" (1997) 24 Journal of Law and Society 124, 132 argue that the likely effect of this responsibility is that it creates "a legal duty of care, owed by the directors to the individual shareholders to whom the information is issued and not to the company as a whole". They also contend that the provision requires directors to give impartial advice on the bid and is likely to have the effect of not allowing them to defend the company in a case where a bid is indeed unwelcome.

${ }^{54}$ The Code, Introduction.
}

64 ibid. 
separately to the duties to act honestly, to recommend an offer which is in the best interests of the company and to not deprive shareholders of the opportunity of obtaining the best price. Nevertheless, as will be made clear, courts have not articulated which factors directors should take into account when considering the interests of the company. One of the most important changes introduced by the Companies Act 2006 is the codification of directors' duties in sections $170-80$, which now directly regulate directors' conduct. However, according to section 170(4) of the Companies Act 2006, the rules will be interpreted and applied in the same way as the common law rules or equitable principles, and therefore an analysis of previous case law in this context is necessary.

There are few cases which are of direct relevance to takeover bids. This has been attributed to the existence of the self-regulation takeover rules found in the Code. ${ }^{55}$ Indeed, since 1968, when the Panel first began to supervise takeovers, the fl ow of takeover litigation to English courts has been reduced, thus not allowing the judiciary to further interpret directors' duties within a takeover context at common law. The cases that have been decided, although somewhat contradictory, remain relevant and shed some light on the target director's role as an adviser. At common law, the main duty that reflects the guidelines which directors need follow when considering their recommendation of a bid to shareholders is the general duty of acting in the interests of the company.

In Gething v Kilner, ${ }^{56}$ the bidder and the target board entered into a financial agreement on the condition that the latter would recommend that stockholders accept the bidder's offer. According to the independent adviser's final report, the offer was inadequate. The target management nevertheless proceeded to recommend the offer, and issued a circular to its stockholders setting out the offer but making no mention of the stockbrokers' adverse advice. The

\footnotetext{
${ }_{55}$ M Nelson-Jones, "Bid Defence, Deal Protection and Directors' Duties" in G Eaborn (ed), Butterworth's Takeovers: Law \& Practice (Butterworths 2005) 327; see also A Johnston, "Takeover Regulation: Historical and Theoretical Perspectives on the City Code" (2007) 66(2) CLJ 422, 440.
}

${ }^{56}$ Gething v Kilner (1972) 1 All ER 1166. 
shareholders of the target brought the matter before court, seeking an injunction to restrain the board from recommending the offer. According to Brightman $\mathrm{J}$, the target directors had a duty to be honest and not mislead their own shareholders. ${ }^{57}$ However, the judge declined to grant the relief sought, because he found that, on the evidence, the board had acted upon the honest and reasonable belief that the offer was advantageous and ought to be recommended to the shareholders. In the case of Dawson International PIC v Coats Paton plc and others, ${ }^{58}$ it was similarly held by the court that target directors are under a duty to recommend a bidder they deem to be beneficial to the company. The cases do not, however, make clear what considerations directors should take into account when recommending a bid they consider to be advantageous or in the interests of the company respectively.

In $R e$ a Company, ${ }^{59}$ rival takeover bids had been made for the shares in a private company. One of the offers was from a company controlled by the target's own directors, whereas the other highest bid was from a competing company. The target board sent a circular to the shareholders advising them to accept the former bid and explained why the latter would not succeed. Shareholders claimed that the directors were in breach of their duty in not recommending the higher offer and in not facilitating the chances of that offer being successful. In his reasoning, Hoffman $\mathrm{J}$ did not accept the proposition that directors are under a "positive duty to recommend and take all steps within their power to facilitate the highest bid". 70 The judge reasoned that, as long as directors provided shareholders with sufficient information to enable them to reach a properly informed decision and did not mislead them, then they would be considered to have acted within their duties.

In Heron International Ltd. $v$ Lord Grade, ${ }^{60}$ the target company was approached by two rival bidders, Bell and Heron. A provision

\footnotetext{
${ }^{57}$ ibid 341.

${ }^{58}$ Dawson International plc v Coats Paton plc and others (1989) BCLC 233.

${ }^{59}$ Re a Company (1986) BCLC 383.

70 ibid.

${ }^{60}$ Heron International Ltd v Lord Grade (1983) BCLC 244.
} 
in the target company's articles of association provided that voting shares could only be transferred to a person nominated by the directors and with the approval of an independent authority. The directors of the company agreed to sell and register the transfer of their own individual share holdings to the first bidder, Bell. When the competing bidder, Heron, eventually made a higher offer, the company was unable to accept it due to the directors' prior commitment. The court found that the power to determine which person shall acquire the shares was a fiduciary duty, which should be exercised in the interests of the company and its shareholders. It held that, under these particular circumstances, the duty imposed on directors according to the articles was to obtain the best price for the shareholders' shares whilst not committing themselves to a bidder, unless he was offering the highest price reasonably obtainable. Seeing, however, that Heron's bid would not have succeeded, since it was conditional on acceptance by an associate of Bell, who was refusing to sell his shares to Heron, the court held that the directors had not acted unreasonably and had not breached their duty when accepting Bell's bid. ${ }^{61}$

In view of the contradictory authorities of Heron and Re a Company, it is unclear whether target directors are under a positive duty to achieve the best price for the company's shareholders. In order to reconcile these judgments, one could logically conclude that the directors are not under a duty to recommend the highest offer as such, but rather to not exercise their powers in a manner that would prevent shareholders from obtaining the best price for their shares. Whereas the cases establish target directors' duties to recommend an offer that is "beneficial to the company" or, otherwise stated, "in the interests of the company and its shareholders", the courts provide for no analysis of the terms. The ambiguity arises from the fact that the law gives directors discretion to make this decision according to their own judgement as to what is good for the company and the

${ }^{61}$ JH Farrar, "Business Judgment and Defensive Tactics in Hostile Takeover Bids" in J Farrar (ed), Takeovers: Institutional Investors and the Modernization of Corporate Laws (OUP 1993) 370-71, where Farrar comments that the legal analysis of the court seems to be close to recognising the Delaware proportionality test. 


\section{FORTHECOMING}

shareholders, without, however, offering guidance as to how this discretion should be exercised and without clarifying to whom directors owe their duties to. Courts at common law have not established factors which would assist directors in constructing their recommendation of an offer to the company's shareholders, placing directors in an ambiguous position when advising shareholders on the prospects of a bid.

\section{The Companies Act 2006 and the EU Takeover Directive}

The legal gap becomes wider once one examines the topic with reference to the provisions of Companies Act 2006. The previous duty to act bona fi de in the interests of the company has now been substituted by section 172 of the Companies Act 2006, which imposes on directors the duty to act in a way that they consider would be most likely to promote the success of the company for the benefit of its members as a whole. The codified duty encompasses directors' fiduciary duties at common law, including the separate duty to act in the interests of the company. Section 172 arguably created a fundamental change to the pre existing duty of directors insofar as it introduces the concept of "enlightened shareholder value" to UK company law. ${ }^{62}$ Section 172 of the Companies Act 2006 is different to prior law insofar as it requires the promotion of the success of the company not on its own right as a separate legal person, but for the benefit of the shareholder constituency as a default priority, and explicitly requires that regard be had to other constituencies when considering what promotes shareholders' interests, so that the standard of care by which appropriate regard is measured has been altered. ${ }^{63}$ At first, the section had given rise to concerns about directors being in breach of their duties if they did not consider every interest group individually in their decisionmaking. ${ }^{64}$ However, it has remained the case that the duty to act in

\footnotetext{
${ }^{62}$ B Davies, "More Than the Bottom Line" New Law Journal (25 July 2008) 1063.

${ }^{63}$ D Kershaw, Company Law in Context (2nd edn, OUP 2001) 382-84.

${ }^{64}$ B Jopson and J Eagelshaw, "Companies Law Reform Threat to Directors" Financial Times (8 March 2006).
} 
the interests of the company has always, save in special circumstances, been owed to the company as a whole and not to individual shareholders or any stakeholders separately. ${ }^{65}$ Shareholders' interests remain the primary focus in corporate board decision-making, but the interests of other corporate constituencies are taken into account as a variable in the equation that guarantees that the corporate interests are being served.

The importance of the reformed duty found in section 172 had lain more in the number of factors which directors were henceforth required to have regard to, including the likely consequences of any decision in the long term. ${ }^{66}$ Section 172 of the Companies Act 2006 may give wide discretion to directors, but it does not determine the standards against which their actions should be assessed. ${ }^{67}$ According to the guidance to the Companies Act 2006 provided by the Department of Trade and Industry, the term "success of the company" reflects what the shareholders of the particular company want to collectively achieve, whilst it is accepted that commercial companies will normally equate success with the company's longterm increase in value. ${ }^{68}$ Furthermore, it is noted that the company's constitution and the decisions made under it will ultimately reflect what the "success model" for the particular company is. ${ }^{69}$ It is in particular stated that "the duty is to promote the success for the benefit of the members as a whole - that is, for the members as a collective body - not only to benefit the majority shareholders, or any particular shareholder or selection of shareholders". ${ }^{70}$

Key to the discussion of the matter with reference to takeovers is the level of divergence of the interests of the company as a whole and the interests of shareholders or the majority of shareholders, which can effectively pass control over the corporation on to a

\footnotetext{
${ }^{65}$ See Foss v Harbottle (1843) 2 Hare 461.

${ }^{66}$ Companies Act 2006, s. 172(1)(a),(b),(c),(d),(e),(f).

${ }^{67}$ J Mukwiri, "Directors' Duties in Takeover Bids and English Company Law" (2008) 19(9) International Company and Commercial Law Review 281, 284.

${ }^{68}$ Department of Trade and Industry, Ministerial Statements, Companies Act 2006, Duties of Company Directors (2007) 7-8, quoting Lord Goldsmith, Lords Grand Committee (6 February 2006, col 258) <http://www.berr.gov.uk/fi les/fi le40139.pdf> accessed 1 January 2014.

${ }^{69} \mathrm{ibid}$ cols 255 and 258.

${ }^{70}$ ibid col 256.
} 
potential bidder. The term "company as a whole" remains an ambiguous term; in common law jurisdictions it is generally equated to "the interests of shareholders". ${ }^{71}$ With reference to this term, both Nelson-Jones ${ }^{72}$ and Sealy ${ }^{84}$ agree that the ruling in the Heron International case should not be considered an authority determining that directors owe fiduciary duties towards the company's shareholders, as distinct from the company, but rather that the court came to this conclusion in view of the fact that a specific article gave the board control over the transfer of the shareholders' voting shares. This view was also adopted in the Dawson International case, in which Lord Cullen confirmed the principle that directors owe their duties to the company and not to the shareholders by stating that:

What is in the interests of current shareholders as sellers of their shares may not necessarily coincide with what is in the interests of the company. The creation of parallel duties could lead to conflict. Directors have but one master, the company. ${ }^{73}$

The preceding arguments presented at common law seem to balance them-

selves in favour of the position that the target directors owe their duties strictly to the company as a whole, save in circumstances where the articles of association provide differently. Indeed, the articles of association could be considered to be a good indicator of whose interests need to be served, and may assist target directors in constructing their recommendation within a takeover bid context. Shareholders' investment ambitions would normally be reflected in the company's articles of association, and shareholders' interests

\footnotetext{
${ }^{71}$ B Clarke, "Takeover Regulation-Through the Regulatory Looking Glass" (2007) 8 German Law Journal, 381, 391.

${ }^{72}$ See Nelson-Jones (n 65) 338, where it is explained that "The court's warning . . . that directors should not commit their own individual shareholdings to a bidder unless they are satisfied that it is offering the best price reasonably obtainable should be read in the context of their exercise of the specific power in the articles ... It is submitted that it should not be read as establishing a general principle that directors owe fiduciary duties to the shareholders . ." ${ }^{84} \mathrm{~L}$ Sealy and S Worthington, Cases and Materials in Company Law (OUP 2008) 626.
}

${ }^{73}$ See Re a Company (n 69) 265. 
should in turn be representative of the types of shareholder to be found in the particular company. However, as the takeover of Cadbury has evidenced, an accurate picture of shareholders' interests and ambitions in relation to their investment in the target company will not always be reflected in the articles of association. The mere announcement of Kraft's bid for Cadbury led even investors with supposedly long-term horizons for the company to sell their shares to hedge funds. ${ }^{74}$ It follows that, as identified by Clarke, the type of shareholders that directors are actually advising may significantly differ from the type of shareholders that founded or formed the company before the bid had been announced. ${ }^{87}$

EU law does not adopt a clear position on the target board's advisory role during a takeover either. ${ }^{75}$ When drafting proposals for the EU Takeover Directive, ${ }^{76}$ there were a variety of controversies surrounding the regulation of the target directors' role. ${ }^{77}$ Against this political backdrop, the Directive now merely offers generic guidelines on the role that target directors need observe during a bid and reflects certain core provisions of the UK Code that have been discussed above. ${ }^{78}$ The Directive provides that the board is under a general duty to give its opinion on the bid and the reasons on which that opinion is based, including its views on the effects of implementation on all the company's interests, with particular reference made to the effects of the bid on employment, the conditions of employment and the locations of the company's places of business. ${ }^{79}$ Article 3(1)(c) of the Directive in particular provides that directors are to act in the interests of the company as a whole. This arguably reflects the notion of directors taking into account

\footnotetext{
${ }^{74}$ B Clarke, "Directors' Duties during an Offer Period-Lessons from the Cadbury PLC Takeover" (2011) UCD Working Papers in Law, Criminology \& Socio-Legal Studies Research Paper No 44/2011, 5 <http://ssrn.com/abstract=1759953> accessed 1 January 2014.

87 ibid.

${ }^{75}$ Directive 2004/25/EC of the European Parliament and Council on takeover bids [2004] OJ L142/12, Recital 17 and arts 3(1)(b), 3(1)(c) and 9(5), provisions which all outline the duties that the offeree board of directors owes to the shareholders of the offeree company.

${ }^{76}$ See Directive 2004/25/EC [2004].

${ }^{77} \mathrm{~J}$ Wouters and others, "The European Takeover Directive: A Commentary" in PV Hooghten (ed), The European Takeover Directive and Its Implementation (OUP 2009) 14-15.

${ }^{78}$ See Section D.1.

${ }^{79}$ See Directive 2004/25/EC [2004] (n 88) General Principles, art 3(1)(b), art 9(5) and Recital 17. PAGES
} 
wider stakeholders' interests, but does not necessarily oblige directors to refer to any particular interest group involved in the process when formulating their opinion of a bid. An attempt had been made by the European Parliament to analyse the concept of "company as a whole" as meaning "the interest of corporate policy and its continuation, shareholders and staff, and with a view to safeguarding jobs". ${ }^{80}$ This term was not, however, endorsed by the Commission on the basis that defining the concept fell outside the objectives of the takeover regulation. This resulted in the undefined and arguably vague expression, "company as a whole", forming part of the Directive's current provisions. ${ }^{81}$

Reference to the various authorities that regulate the advisory role of the target directors during a takeover bid has highlighted the difficulties the directors may be faced with when formulating their opinion of a bid to shareholders. The following section will attempt to identify the particular areas of difficulty and elaborate on the inconsistencies found within the broader regulatory framework.

\section{E. THE LEGAL UNCERTAINTIES: GREY AREAS OF LAW IN RELATION TO THE ADVISORY ROLE OF TARGET DIRECTORS}

As has been made clear in section D above, the law offers little guidance to target directors on how to construct their opinion of a bid to shareholders. In recommending an offer, target directors are faced with the difficult issue of determining which interests they should have in mind, be they the company's or the shareholders', and settle on the extent to which one overlaps with the other. ${ }^{82}$ In the Kraft-Cadbury takeover, target directors were focused on the target price of the predominant ${ }^{83}$ type of shareholder within the company, namely hedge funds, so that, when they finally recommended the bid, the protection of the interests of the company as a whole was no

\footnotetext{
${ }^{80}$ See Amendment 5 of the European Parliament, voted 13 December 2000, after second reading.

${ }^{81}$ See Wouters and others (n 90) 14-15.

${ }^{82}$ See Nelson-Jones (n 65) 330.

${ }^{83}$ Note that the predominant shareholder is termed as predominant on the basis that the said type of shareholder possesses the necessary amount of shares which is required to realise a change of control in the target company.
} 
longer on their agenda. As explained by Roger Carr, Cadbury's former CEO, it had been evident from the outset that the success of the deal was to be intricately linked to the offer price, and other variables were unlikely to be taken into account. ${ }^{84}$

Despite recent amendments to rule 25.1 of the Code, grey areas of law on the factors that directors can take into account when preparing their opinion of an offer remain. The jurisprudence focusing on directors' duties within a takeover context fails to elaborate on these factors and is significantly outdated. ${ }^{85}$ Interpreting the applicable rules with cross reference to various authorities is also of limited help, since directors' statutory obligations are not highly consistent with the rather passive duties that the Code imposes on directors. This section will elaborate on the inconsistencies found within the regulatory framework, highlighting the dilemmas target directors may be faced with when called to advise on the merits of a bid.

Though the Panel was prompted to review its rules as a matter of political enquiry, it was in fact averse to the notion of taking into account issues related to the financial or commercial disadvantages of bids. ${ }^{86}$ Conversely, however, in its report, the Code Committee concluded that hostile offerors have in recent times been able to gain a tactical advantage over the offeree company to the detriment of the offeree company and its shareholders. ${ }^{87}$ In light of this, it accepted that it needed to amend the Code not only to reduce the tactical advantage and redress the balance in favour of the offeree company, but also to improve the Code so that it would take more account of the positions of the persons who are affected by takeovers in addition to offeree company shareholders. ${ }^{88}$ In this respect, the additional

\footnotetext{
${ }^{84}$ See Carr (n 31); see also Clarke (n 86) 5.

${ }^{85}$ Note that this is due to the fact that the $\mathrm{fl}$ ow of litigation to courts has significantly decreased ever since the Panel assumed its role in 1968.

${ }^{86}$ See First Response Paper (n 11) 2, s 2(2), where the Panel, quoting s 2(a) of the Introduction to the Code, emphasised in its statement that: "The Code is designed principally to ensure that shareholders are treated fairly and are not denied an opportunity to decide on the merits of a takeover . . . The Code is not concerned with the financial or commercial advantages or disadvantages of a takeover. These are matters for the company and its shareholders."

${ }^{87}$ See First Response Paper (n 11) 3, ss 2.6 and 2.7.

${ }^{88}$ See First Response Paper (n 11) 3, ss 2.6 and 2.7.
} 


\section{FORTHECOMING}

interpretive text to rule 25.2 in the new edition of the Code is a step forward, as it makes clear that the board of the offeree company can take into account other factors, besides the share price, when giving its opinion on an offer. ${ }^{89}$ The recently added interpretive text has nevertheless failed to resolve the ambiguity related to the factors that target directors can in fact take into account when advising on a bid. Prior to the amendment in question, the target board could formerly rely on section 172 only if it did in fact decide to recommend rejection of a bid to its shareholders on the grounds of safeguarding the long-term continuity of the fi rm to the benefi $t$ of its members as a whole. However, there is a high level of uncertainty with regard to the application of section 172 of the Companies Act 2006 within a takeover situation. ${ }^{90}$ It may well be the case that section 172 does not apply in a takeover context, because the provisions of the Code taking precedence as a special law. Guidance as to the relationship that exists between the Code and general UK company law is minimal. It has been made clear that the Code, as an autonomous body of rules, should not be interpreted with reference to company law statutes, and that its provisions should be given an autonomous meaning according to the aims of the Code. ${ }^{91}$ However, there are no authorities conclusively establishing how the different sources of law apply parallel to the Code and whether the Code takes precedence over the general UK company law with regard to the duties discussed, within a takeover context. If one assumes that section 172 does, however, apply parallel to the Code, it is unclear how directors should balance the long-term interests of the company with their duty to consider whether the bid is fair for present shareholders. ${ }^{92}$ As Deakin identifies:

\footnotetext{
${ }^{89}$ See the Code, notes on r 25.2, point 1.

${ }^{90}$ Corporate Briefing by Herbert Smith, "Takeovers in the UK-Review of Topical Issues and Code Changes over the Last 12 Months" (November 2005) 2 <www.herbertsmith.com/ NR/rdonlyres/EE2949E7-B4A6-4969-9185-4E666CA752F5/1672/5373TakeoversintheUKar eview2.pdf> accessed 1 January 2014.

${ }^{91}$ See Kershaw (n 52) 46-47, where, in support of this argument, Kershaw refers to the decision of the Appeal Board in Eurotunnel [Takeover Appeals Board 2007/2].

${ }^{92}$ See Corporate Briefing by Herbert Smith (n 103) 2.
} 
neither the Code, nor the general law of fiduciary obligation, provides any mechanism for determining how conflicts between the interests of different groups should be dealt with, nor are the courts likely to see themselves as equipped to evaluate decisions taken by the board in good faith under the business judgment rule. ${ }^{93}$

It has been argued that the section should be interpreted in such a way that the other interests referred to, such as those of employees, are taken into account only in relation to promoting the long-term success of the company as indicated in section 172 of the Companies Act 2006 and only in relation to shareholders' future interests, which would continue to take priority. ${ }^{94}$ However, even if one follows this narrow analysis of how section 172 of the Companies Act 2006 applies within a takeover context, there exist varied terms which need be elaborated on further. What is meant by "the interests of the company" as stipulated in section 172 of the Companies Act 2006 and General Principle 3 of the Code? Which shareholders' interests should be taken into account? Are they the interests of the majority of shareholders that are empowered to realise the change in corporate control or the interests of shareholders as a collective group, present and/or future? Also, to what extent do the interests of the company as a whole diverge from the interests of shareholders, whatever those may be?

Contrary to the notion that directors owe their duties to the company and not to shareholders, as analysed above in Section D.3, it has been suggested that, within a takeover context specifically, directors are in fact acting solely as agents of the target shareholders, advising them on their investment and guiding them through the overall takeover process. ${ }^{95}$ This special relationship between directors and shareholders during a takeover is elaborated on by Mukwiri, who explains that, despite it generally being the case that directors owe their fiduciary duties to the company, takeovers fall

\footnotetext{
${ }^{93}$ See Deakin and Slinger (n 62).

${ }^{94}$ See Rybak (n 4) 413.

${ }^{95}$ See Mukwiri (n 78) 282.
} 
within the exclusion of that principle. ${ }^{96}$ This point of view asserts that takeovers qualify as a particular case in which a special factual relationship between the directors and the shareholders can be established, meaning that directors will owe their duties to shareholders directly. ${ }^{97}$ Deakin and Singh reaffirm this position by arguing that the fact that the Code obligates the boards of the target and the bidder to issue a separate document that declares that the directors accept responsibility for the information contained in any statements they issue suggests that the Code imposes a duty of care owed by directors to target shareholders directly, and not the company as a whole. ${ }^{98}$ In Re Chez Nico (Restaurants) Ltd, ${ }^{112}$ BrowneWilkinson VC acknowledged that, although, in general, directors owe fiduciary duties to the company, certain special circumstances may arise when fiduciary duties, carrying with them a duty of disclosure, will place directors in a fiduciary capacity visà-vis the shareholders. Similarly, in Allen $v$ Hyatt, ${ }^{99}$ the court reasoned that, within a takeover context, directors' duties should be treated as owed to shareholders as a group, and not solely to the company.

Defining the notion of advising with respect to "the interests of the company as a whole" within the context of a takeover bid poses a special challenge. Socio-political concerns were heightened after the financial crisis emerged and have thus tested how the term the "company as a whole" should be interpreted henceforth. ${ }^{100}$ At present, one could rightly argue that the phrase should be interpreted to encompass broader stakeholder interests in light of the

\footnotetext{
$96 \mathrm{~J}$ Mukwiri, Takeovers and the European Legal Framework: A British Perspective (RoutledgeCavendish 2009) 86-87, in which Mukwiri identifies that the Code itself makes clear that during a course of a takeover bid target directors are in essence viewed upon as the agents of the shareholders and not the company as a whole.

${ }^{97}$ Peskin v Anderson [2001] BCC 874; see also Mukwiri (n 109) 80.

${ }^{98} \mathrm{~S}$ Deakin and A Singh, "The Stock Market, the Market for Corporate Control and the Theory of the Firm: Legal and Economic Perspectives and Implications for Public Policy" (June 2008) Centre for Business Research, University of Cambridge Working Paper No 365, 10-11. ${ }^{112}$ Chez Nico (Restaurants) Ltd [1991] BCC 736.

${ }^{99}$ Allen v Hyatt [1914] 30 TLR 444; see also Mukwiri (n 109) 86-87, where Mukwiri comments, with regard to this case, that "the Privy Council held the directors accountable to shareholders for the profit the directors had made on shares".

${ }^{100}$ See Rybak (n 4) 423.
} 
implementation of the EU Takeover Directive, allowing a departure from the strict shareholder primacy that has dominated UK company law. In fact, if General Principle 3 is read together with the newly added interpretive section to rule 25.1 of the Code and the enacted section 172 of the Companies Act 2006, which introduces the "enlightened shareholder value" approach in corporate decisionmaking, the phrase could be interpreted in its broadest sense. Considering that the Code's main objective remains to provide shareholders with accurate and complete information in their decision to tender their shares, though, General Principle 3 could simply be read as implying that the corporate interests are to be taken into account "for the benefit of the company's members". Following this view, the section should be read merely as a provision which allows directors to defend the continuation of the targeted company as an independent entity, estimating its profitability for future shareholders by taking into account other constituencies' status quo and the corporation's strategy overall. As Kershaw has rightly identified, in the UK, when examining directors' duties at common law, the term "company interests" basically equates to the interests of current and future shareholders, with the interests of other constituencies forming only part of the equation. ${ }^{101}$

A characteristic case study that is relevant to our discussion of the term encompassed in General Principle 3 is that of the proposed takeover of Manchester United in 2005, whereby the board of the target company explained that, although the offer made by the bidder Malcolm Glazer was a fair price for its shareholders, it did not recommend the deal on the basis that it was not in the best interests of the target company. ${ }^{102}$ As explained, the deal was considered to potentially put pressure on Manchester United's business, as the offer would potentially impose a high debt burden on the company. ${ }^{117}$ This case study is an important one, as the target

\footnotetext{
${ }^{101}$ See Kershaw (n 52) 46-47.

102 See Manchester United Plc, "Club Responds to Glazer" (11 February 2005) <http://www. manutd.com/default.sps?pagegid=\%7BB4CEE8FA\%2D9A47\%2D47BC\%2DB069\%2D3F7A2 F35DB7 0\%7D\&newsid=150184> accessed 1 January 2014. 
directors considered what was in the best interests of the target separately from their strict obligations as outlined in the Code. ${ }^{103}$

Deakin and Singh have pointed out that, under the older regime of the Code, even though directors were in fact in a position to advocate that a hostile bid was contrary to the company's long-term planned strategy, they were nevertheless bound to observe their duty in providing an objective financial assessment of the bid in their opinion. ${ }^{104}$ The amended version of rule 25.1 of the Code may now offer some leeway for directors to consider the offer beyond its strict financial merits. This qualifies as a step forward, as there may well be a variety of cases in which a bid is not in the interests of the company but does, however, offer a fair price to the current shareholders for their shares. How exactly directors should advise when faced with a conflict between their duties at common law and duties as stipulated in the Code nevertheless remains unresolved. When interpreting the term, however, it has been rightly observed that the Panel will need to take a purposive approach to ensure compliance with the Directive ${ }^{105}$ and in this respect should, as Sjåjfell has pointed out, be given an autonomous broader European meaning instead. ${ }^{106}$ This section has highlighted the complexity of applying directors' duties as enacted in the Companies Act 2006 and interpreted at common law in a takeover situation, parallel to the duties as outlined in the Takeover Code. It has also reported on the inherent difficulty in interpreting the phrase used in General Principle 3 of the Code "in the interests of the company as a whole". Legal uncertainty about how the rules are to be applied results in unfair results not only for market participants, such as target and bidding shareholders, but also for other constituencies that may be affected by a change in corporate control. Regulators should thus reconsider outlining the factors which directors should take into

\footnotetext{
${ }^{103}$ See Corporate Briefi ng by Herbert Smith (n 103).

${ }^{104}$ See Deakin and Singh (n 111) 11.

${ }^{105}$ See Kershaw (n 52) 46-47.

${ }^{106}$ B Sjåfjell, Towards a Sustainable European Company Law: A Normative Analysis of the

Objectives of EU Law, with the Takeover Directive as a Test Case (Kluwer Law International 2009) 350 .
} 
account when considering their recommendation of a bid to shareholders, enact provisions that clarify to whom exactly target directors owe their duties during a takeover and explain how directors should prioritise those interests.

The next section reviews literature that questions the efficient operation of markets in their strongest form, highlighting target directors' advantageous position in possessing information on the company that may well not be publically available. Guidelines on how target directors should assess the merits of a bid would allow directors to methodically fill in the gap created 117 ibid by the suggested informational asymmetry. The fact that a bidder's motives for acquiring the company may vary constitutes an additional argument in support of strengthening the advisory role of target directors.

\section{F. THE MARKET FOR CORPORATE CONTROL: UNDERLYING ISSUES}

An open market for corporate control not working effectively to oust underperforming companies from the market can be explained on a twofold basis. The first explanation is that the market efficiency theory which constitutes the backbone of takeovers' correct operation does not operate in practice as theory suggests. ${ }^{107}$ Secondly, it is often the case that target companies are not underperforming but are targeted for other reasons, depending on the acquirer's motives.

Efficient markets constitute the backbone of the takeover's effective operation. The market efficiency theory purports that stock market investors behave rationally and thus shares are priced so as to reflect the company's performance and prospects. It follows that, in the case of lowered share prices, management of the particular

\footnotetext{
${ }^{107}$ For a general review of the Market Efficiency Hypothesis see E Fama, "Efficient Capital Markets: A Review of Theory and Empirical Work" (1970) 25(2) Journal of Finance 383. ${ }^{123}$ M Wachter, "Takeover Defense When Financial Markets Are (Only) Relatively Efficient" (2002) Institute for Law \& Economics Research Paper No 02-19, 15 <http://ssrn.com/ abstract=330620> accessed 1 January 2014.
} 
company may be replaced through a takeover performed by another company, typically conducting similar business to the target. The ultimate goal is to utilise the target's assets more effectively and make it profitable. Wachter makes an outline of the issues associated with the efficient capital market hypothesis by explaining it in its three forms: weak, semi-strong and strong. The first form suggests that the prices are determined according to information on past market prices, not allowing investors to accurately predict future ones. The second form suggests that prices are the result of past, as well as present publically available information, whilst the last form suggests that share prices encompass private as well as public information. ${ }^{123}$ Manne is as the fi rst and supreme advocate of the use of takeovers as an ideal corporate governance mechanism that can correct managerial inefficiency in firms in which there is a distinct separation between ownership and control. ${ }^{108}$ As Höpner and Jackson identify:

Manne's theoretical innovation was to posit a strong relation between share prices and managerial performance and thereby to discover a new market based governance mechanism compatible with the exit preferences of small shareholders. As shareholders respond to poor managerial performance through exit, the lower share prices create incentives for outsiders to accumulate control rights, replace the management team, and restructure the underperforming fi rm. ${ }^{109}$

Therefore, whether the market can appropriately reflect the value of the company, or in fact reflects how efficient a company's management is, determines how effective takeovers are in achieving their aims. The proper function of the market for corporate control is thus dependent on the market efficiency theory functioning as the

\footnotetext{
${ }^{108}$ See Manne (n 1) 118; see also K Lehn, "Some Observations on Henry Manne's Contributions to Financial Economics" (2000) 50 Case Western Law Review 263, 264.

${ }^{109}$ M Höpner and G Jackson, "An Emerging Market for Corporate Control? The Mannesmann Takeover and German Corporate Governance" (2001) MPIfG Discussion Paper 01/4, 9 〈http://www.mpifg.de/pu/mpifg dp/dp01-4.pdf > accessed 1 January 2014.
} 
theory suggests. ${ }^{110}$ The workings of an open market for corporate control are therefore challenged when there is evidence which suggests that the market efficiency theory does not apply in its strongest form. ${ }^{111}$ The problem is identified by Deakin and Slinger, who explain that:

it need not be the case that a short-term change in the share price accurately reflects the future value of the company. While this would follow if the efficient capital market hypothesis were correct, there is evidence to suggest that share price movements have only a limited connection to managerial performance either prior or subsequent to a takeover. ${ }^{112}$

The share price as such not being the single indicator of the company's present and future prospects makes target directors' advice towards shareholders of vital importance. Target directors may possess and reflect on information which may not be available via market indicators. Target boards' advice can thus fill in the informational gaps created by the operation of a semi-strong as opposed to a strong form of the efficient capital market hypothesis regarding the efficiency of markets. Target directors, who will have information about the future value of the company which the market does not, should communicate this in their advice and should be given guidelines as to how this duty should be undertaken. Detailed regulation would thus foster the target directors' ability to reflect upon the bid beyond its strict financial merits, which the market or the financial advisers called to the task may not appreciate.

Because the share price may not be a true indicator of the company's present performance and prospects, it is also the case that, although in theoretical terms the bidder may aim to acquire a company that is underperforming, there is evidence to suggest that the bidder's motives are not always associated with the intent of improving the management of the target. ${ }^{113}$ Agrawal and Jaffe,

\footnotetext{
${ }^{110}$ See Clarke (n 6) 21-22.

${ }^{111}$ See Parkinson (n 1) 123.

112 See Deakin and Slinger (n 62) 132.

${ }^{113}$ See Parkinson (n 1) 123.
} 
finding cases in which the target company is underperforming and cases in which it is not, try to reconcile their findings. They explain that the motives of the bidder may vary, so that acquisitions are not always aimed at correcting poor performance of the target firm, whilst those that do may only constitute a small percentage of all the acquisitions undertaken. ${ }^{114}$ After questioning the market's absolute ability to oust underperforming companies with inefficient management from the market, the following section will explain the value of directors' advice within this context, and specifically the determinants that directors are likely to take into consideration during a takeover.

\section{G. TARGET DIRECTORS' ADVICE: THE "COMPLEMENTARY TOOL" ARGUMENT}

Empirical evidence shows that the target board's resistance to a bid is "inversely related to the probability of its success". ${ }^{115}$ Data focusing on UK takeover activity taking place within a four-year period ending on 31 March 2010 finds that, out of the 472 offers formally announced during that period, 15.3 per cent were not recommended by the board of the offeree company, and, of those which remained unrecommended at the end of the offer period, only 5.7 per cent were successful and 2.8 per cent lapsed. ${ }^{116}$ Wong and O'Sullivan also show that the main cause of takeover failure is opposition from target management and that, once target management opposes a takeover, the probability of a bid succeeding falls by 50 per cent. ${ }^{117}$

\footnotetext{
${ }^{114}$ A Agrawal and J Jaffe, "Do Takeover Targets Underperform? Evidence from Operating and Stock Returns" (2003) 38(4) Journal of Financial and Quantitative Analysis, 742.

${ }^{115}$ P Holl and D Kyriazis, "The Detriments of Outcome in UK Take-over Bids" (1996) 3(2) International Journal of Economic Business 168; see also P Wong and N O'Sullivan, “The Determinants and Consequences of Abandoned Takeovers" (2001) 15(2) Journal of Economic Surveys 156.

${ }^{116}$ See First Consultation Paper (n 25) 4.

${ }^{117}$ See Wong and O'Sullivan (n 131) 181; however, despite there being a correlation between opposition and bid failure, care should be taken in interpreting the evidence by Wong and O'Sullivan as this does not necessarily suggest that the opposition causes failure.
} 
The significance of target board recommendations on takeover outcomes, coupled with the fact that the efficient capital market hypothesis is not applicable in its strongest form and the possible varied motives behind launching a takeover, is why the proposal of strengthening the target directors' advisory role through detailed regulation is considered worthwhile. In view of the fact that even the most sophisticated institutional investors are unlikely to possess as much information on the company's business and future prospects as does the board of the target company, ${ }^{118}$ it is argued that the recommendation made by the target board of directors could well constitute a complementary tool for ensuring that the correct decision is made on the bid.

In general terms, there are two main hypotheses used to explain how target directors may choose to construct their recommendation to target shareholders once an offer for the company has been made, namely the "director welfare hypothesis" and the "shareholder welfare hypothesis". ${ }^{119}$ In the first hypothesis, target directors are assumed to construct a recommendation on grounds of self-interest, whilst in the second they will advise in the best interests of the shareholders. Empirical evidence using data from 400 takeover bids for Australian listed companies and a univariate and multivariate analysis shows that target directors do tend to recommend accepting or rejecting a bid according to the company's shareholders' interests rather than their own. ${ }^{120}$ On a theoretical level, the UK legal framework is also considered to confine directors to a satisfactory level within the limits of not advising on grounds of self-interest. ${ }^{121}$ It may well be argued that the problem of directors advising against

\footnotetext{
${ }^{118}$ See Kershaw (n 52) 68-69, who also points out that that directors often possess confidential information on the company's business, which has not been disclosed to shareholders in fear of that information being used by competitors to the company's disadvantage; see also SCY Wong, "Long-Term versus Short-Term Distinction in UK Takeover Review Misses the Point" (2010) 2 <www.ssrn.com/abstract=1662610 > accessed 1 January 2014, who points out that insider

${ }^{119}$ PH Eddy and RS Casey, "Director's Recommendations in Response to Takeover Bids: Do They Act in Their Own Interests?” (1989) Australian Journal of Management 2.

${ }^{120}$ ibid 26.

${ }^{121}$ For provisions of the Code on conflicts of interest see Kershaw (n 52) 69; for other common law and statutory provisions see D Kershaw, "The Illusion of Importance: Reconsidering the UK's Takeover Defence Prohibition” (2007) 56(2) ICLQ 267.
} 
a bid because they fear losing their jobs is significantly limited by the fact that target directors' conduct is regulated through the duty to act within their authority and not exercise their powers for improper purposes, the general duty to act in the interests of the company and the duty to avoid a situation in which they are faced with a conflict of interest. ${ }^{122}$ Thus, arguments of advising on grounds of self-interest aside, it is worth elaborating on the factors that are likely to influence directors in their assessment of an offer with respect to shareholders' interests. The target directors' recommendation may encompass information that shareholders may constructively utilise in reaching a decision on the true merits of the bid. It will be argued that the type of consideration given to target shareholders in exchange for their shares, as well as the identity of target shareholders in terms of their investor horizon, are bid and firm

trading rules may also not allow shareholders to fully appreciate why a certain bid undervalues the target company and why they should for such reasons choose to reject it. Also note that, in hostile takeovers especially, where target directors do not disclose all necessary information on the target's business to the acquirer, it is consistent that the acquirer will not be able to commit to a transparent and public announcement of its long-term plans for the assets and human capital of the enlarged corporate entity to be formed after the acquisition.

characteristics, respectively, that determine the likelihood and content of the target board's recommendation.

${ }^{122}$ Within a takeover context directors are subject to a combination of common law, statutory and selfregulation rules, including the proper purpose doctrine (s 171(b) Companies Act 2006), the duty to act in the interests of the company (s 172 Companies Act 2006) and the duty to avoid a conflict of interest situation (ss 175 and 177 Companies A 2006). The Code also specifically regulates target directors' conduct were conflict of interest situations may arise (see, eg r 3.2 and notes on $\mathrm{r}$ 25.2 of the Code). 


\section{Paper versus Cash Consideration for Shares}

In terms of consideration, the bidder may elect to acquire the target company by making either cash or paper consideration, or even a combination of cash and equity, for the target company's shares. ${ }^{123}$ When shareholders are offered shares in the newly created company in exchange for their existing shares, information on the newly formed company's prospects will be of significant interest. ${ }^{124}$ In the case of paper consideration, the target board may consider the financial condition of the offeror and, if unacceptable, propose for shareholders to reject the bid. ${ }^{125}$ As Stedman explains:

where paper is being offered or must feature at least as part of the consideration (eg in "mix and match" elections) the target board has considerable scope to attack the performance, gearing and financial position of the offeror, as acceptance of the offer will constitute an investment by the target's shareholders in favour of the offeror. ${ }^{142}$

When there is a paper consideration for shares, the offeror's intentions for the company's business and employees become highly relevant. Shareholders enabled to receive information about the target's business prospects can make a constructive decision about the acquisition considering, inter alia, the effect of a takeover on other constituencies of the company that may be of importance. ${ }^{143}$ In contrast, when a cash offer is made it is likely that the effect of the takeover on corporate constituencies will not be of interest to shareholders. In such a situation, shareholders' main focus is likely to be on the best price obtained for their shares. However, even in such a situation there is a difficulty in deciding whether shareholders' interests lie more in maintaining their shares in the current company in the long run compared to the option of exiting the company with an immediate beneficial financial return by

\footnotetext{
${ }^{123}$ See Wong and O'Sullivan (n 131) 147.

${ }^{124}$ See Kershaw (n 52) 66-67.

${ }^{125}$ G Stedman, Takeovers (Longman 1993) 407. 142 ibid. 143

ibid.
} 
accepting the bid. The question ultimately asked is whether shareholders are assumed to profit more by selling their shares in the immediate future or holding on to them as an investment in the target company.

In a bid with paper consideration made for the company, the bidder and the target directors are likely to take into account the wider interests of the target company's shareholders in the discharge of their respective fiduciary duties. ${ }^{126}$ In such a situation it will also become necessary to assess the bidder against the target company's corporate strategy and objectives. The information required will likely centre around the corporate strategy of the bidding company and its intentions with regard to the protection of the company's constituencies. The governance and strategy of the bidder will then be compared against the governance and strategy that the target firm has set in place. The future profitability of the target company becomes of relevance, and profit forecasting is the necessary means through which such a comparative assessment is effected. The Code recognises the obvious hazards in drafting up such forecasts and imposes that in drafting them it is necessary to maintain the highest standards of accuracy. ${ }^{127}$ The problem with profit forecasting, though, is that it is based on highly speculative assumptions. ${ }^{128}$ In order to mitigate the uncertainty created, the Code requires the disclosure of the assumptions on which the forecasting is based, ${ }^{129}$ and it also imposes separate duties on the financial advisers and on the auditors that the information contained is accurate and that the procedures have been properly complied with, respectively. ${ }^{130}$

When one is to compare the two payment scenarios, namely paper or cash considerations for shares, overall, shareholders are no doubt

\footnotetext{
${ }^{126}$ See Deakin and Slinger (n 62); see also Johnston (n 65) 455, who highlights that target directors' duties towards employees or the future management of the fi rm could also become more relevant at the stage when directors are considering rival bids and are asked to judge which bid would

${ }^{127}$ The Code, r 28.1.

${ }^{128}$ See Kershaw (n 52) 67.

${ }^{129}$ The Code, r 28.2 .

${ }^{130}$ For duties of financial advisers and auditors see the Code, note 1(c) to $r$ 28.2; and r 28.3(a)-(c).
} 
faced with more uncertainty when the method of payment chosen is equity as opposed to cash. ${ }^{131}$ Wong and O'Sullivan explain that:

If a bid is financed by cash the precise value of the bid to target shareholders is known and consequently shareholders possess better information when deciding whether to accept or reject a bid. However, bids financed by equity involve a greater degree of uncertainty for shareholders since the value of a bid is contingent upon the bidder's future management of the combined company. ${ }^{150}$

In either case, however, and no matter the degree of uncertainty, the target board has the ability to provide extensive information on the company's offer better prospects to the company's constituencies; strategy, since target board directors are privileged with better information on the true value of the target company than the acquirer and can therefore better estimate its future prospects. Once the information is communicated by the target board, it will be available to the bidder as well. The effect that the paper versus cash offer may have on the target directors' opinion of a bid was also reflected in the Cadbury deal. In the case of the takeover of Cadbury, the initial offer made by Kraft to Cadbury's shareholders was 60 per cent stock and 40 per cent cash, whereas later on, in January 2010, when Kraft raised its offer, it also changed the stock-cash proportion to 40 per cent stock and 60 per cent cash. ${ }^{132}$ This change may have arguably contributed to the Cadbury target board's decision to finally recommend the offer to its shareholders and refrain from attacking Kraft's weak performance in their final recommendation.

\section{The Identity of the Target Shareholders}

It was argued that hedge funds were an easy target to blame in the aftermath of the successful takeover of Cadbury, ignoring the fact that so-called long-term investors also sought to capitalise on their

\footnotetext{
${ }^{131}$ See Wong and O’Sullivan (n 131) 162.

150 ibid.

${ }^{132}$ See Wiggins (n 38).

${ }_{152}$ ibid.
} 
investment. ${ }^{152}$ Reaching the target price may explain why, at the mere announcement of the bid to take over Cadbury, many so-called long-term investors gradually elected to profit from their investment by selling their shares to short-term investors, such as hedge funds. ${ }^{133}$ Concerns about so-called short-term investors, such as hedge funds, deciding on the future of companies were thus one of the basic drivers for the reform of the UK takeover rules. Hedge funds in particular not only adopt complex investment strategies, ${ }^{134}$ but are also characterised by operating in a very short time period when realising returns to their own private investors. ${ }^{135}$ The main accusation against hedge funds is that their strategy involves achieving a short-term profit at the expense of long-term profitability. ${ }^{136}$ One of the different strategies followed by hedge funds in particular is short-selling, which as a practice is based on the phenomenon of "market myopia", meaning that current share market prices are not accurate. ${ }^{137}$ As explained by Kahan and Rock, if such a bias does not exist in the market, then the interests of shareholders with long-term horizons and those with short-term horizons will not diverge. ${ }^{138}$ Conversely however, if the bias does exist, the interests of different types of shareholders diverge. The identity of the shareholder to whom advice is being given thus becomes relevant.

Despite the material differences discussed in Section G.1, paper and cash consideration for shares can also attract different types of shareholders. A cash consideration for shares often attracts shareholders who acquire shares upon announcement of a bid, when the price of shares will be below the price estimated to be offered upon acquisition, with the aim of selling once the takeover proceeds

\footnotetext{
${ }^{133}$ See Clarke (n 86) 5; see also Wong (n 134) 2, who reports that Cadbury's shareholders had been offered a premium of more than $30 \%$ at the beginning of takeover announcement which fi nally increased to a $50 \%$ when the offer was officially made.

${ }^{134}$ DA Oesterle, "Regulating Hedge Funds" (2006) 1(1) Entrepreneurial Business Law Journal 1, 5. 135 ibid 4.

${ }^{136}$ M Kahan and EB Rock, "Hedge Funds in Corporate Governance and Corporate Control" (2007) Scholarship at Penn Law, Paper 99, 1022 <http://lsr.nellco.org/upenn_wps/99> accessed 1 January 2014.

137 ibid $1033-34$.

138 ibid 1084-85.
} 
and a higher price is offered. ${ }^{139}$ Alternatively, a practice often observed in an offer of paper consideration for shares is merger arbitrage, whereby a merger arbitrageur shareholder will buy shares in the target company and sell short the shares in the bidding company with an aim of covering his short position in the acquiring company once the takeover is complete by owning the converted shares of the bidding company. ${ }^{160}$

Despite the "maximisation of shareholder wealth" being adopted as the norm in corporate decision-making in the Anglo-Saxon models of corporate governance, an important aspect of this norm which has been overlooked by past research is "who exactly is the 'shareholder' to whom ... [directors] hold themselves accountable". ${ }^{140}$ Also, although, in terms of ownership, public corporations will comprise a variety of types of investors, directors assume to serve the interests of "a generic 'fictional shareholder' abstraction". ${ }^{141}$ As Crespi explains:

Moreover, the law does not impose any particular definition of this hypothetical shareholder, which leaves directors with the discretion to choose among a wide range of possible fictional shareholder characterizations to guide them in their investment decisions. The choice of characterization used may well have significant consequences for those decisions. ${ }^{142}$

Within a takeover context in particular, the identity of the predominant shareholders in the firm at the time a bid is made for the company's shares is in fact likely to determine the likelihood and content of the target board's recommendation on the bid and ultimately of a takeover. Sunderland, the former Chief Executive Officer of Cadbury, claimed that the Takeover Code was outdated

\footnotetext{
139 Barclay Hedge Alternative Investment Databases, "Understanding Merger Arbitrage" < http:// www.barclayhedge.com/research/educational-articles/hedge-fund-strategy-defi nition/hedgefundstrategy-merger-arbitrage.html> accessed 1 January 2014.

160 ibid.

${ }^{140}$ GS Crespi, "Maximising the Wealth of Fictional Shareholders: Which Fiction Should Directors Embrace?" (2007) 32 Journal of Corporation Law 381, 383.

141 ibid 383.

142 ibid 383-84.
} 


\section{FORTHECOMING}

insofar as it did not reflect the new ownership models that had arisen over the past couple of decades. ${ }^{143}$ Different types of shareholders will normally have a different investment horizon, meaning the time frame within which each type of shareholder will aspire to see a return on his investment. Wong and O'Sullivan conclude that:

in the UK little work has examined pre- and post-bid governance characteristics of targets and bidders-specifically seeking to determine whether unsuccessful bids actually change the type and quality of monitoring employed by shareholders. The high levels of institutional ownership in UK companies compared to the US, suggests that an analysis of the role of such institutions, both in determining bid outcome and implementing post-abandonment reforms, may be especially useful. ${ }^{144}$

Arguably, though, all investors have a "target price" for the company, meaning their evaluation of their investment in the company. ${ }^{145}$ This price varies according to the type of investor and changes in light of developments at any given period in time. ${ }^{167}$

As mentioned in Section D.1, the main objective of the Code is to ensure that shareholders have been provided with complete and accurate information on the offer, so as to ensure that they will in fact make an informed decision on whether or not to tender their shares. As Kershaw points out, there is a divergence between the way in which the relevant provisions are assumed to work in theory and how they in fact may often operate in practice. ${ }^{146}$ Kershaw explains that the provisions of the Code appear to be addressing a type of shareholder who has an interest in acquiring the information offered, and who will also devote time to assessing that information so as to make a decision on the bid. ${ }^{169}$ However, in practice, certain types of investors will attach a minimal value, if any, to the

\footnotetext{
${ }^{143}$ See Wiggins (n 38).

${ }^{144}$ See Wong and O’Sullivan (n 131) 182.

${ }^{145}$ See Wong (n 134) 2.

167 ibid.

${ }^{146}$ See Kershaw (n 52) 72-73.

169 ibid.

170 ibid.
} 
information provided and contained in the target board's opinion of a bid. ${ }^{170}$ One of the corporate strategies of hedge funds as shareholders of the target firm is to form a temporal obstacle to the bidder's acquisition, improve the terms of the offer and sell once the target price has been reached. ${ }^{147}$ The interests of other institutional shareholders that may have remained as investors in the target company may well diverge from those of the hedge funds that follow such practices. ${ }^{148}$ It is also not uncommon for so-called long-term shareholders to immediately dispose of their shares upon announcement of a potential takeover bid to other interested investors, such as hedge funds. ${ }^{149}$ When an increase in the target firm's share price is marked upon announcement of a potential takeover bid, certain shareholders will choose to trade their shares at this early point in time, so as to transfer the risk of the bid not being successful to other shareholders willing to assume it. ${ }^{174}$ Despite the existence of shareholders, such as hedge funds, that will possibly attach minimal or zero value to the target board's opinion of a bid, there remain certain types of shareholders that will benefit from the information provided. ${ }^{150} \mathrm{~A}$ shareholder that would in fact value the target board's elaborate opinion of a bid, would be the type of shareholder that Strine identifies in his paper, when he states that there are investors that:

do not care to pump up stock prices in the short term if that endangers the firm's solvency and long-term growth prospects . . . In sum real investors want what we as a society want and we as end-user, individual investors want; which is for corporations to create sustainable wealth. ${ }^{151}$

Examining investor patterns in Cadburys plc over time may provide an insight into the discussion on whether shareholders' interests

\footnotetext{
${ }^{147}$ See Kahan and Rock (n 156) 1037.

148 ibid 1022.

${ }^{149}$ Kalirai (n 144).

${ }^{150}$ See Kershaw (n 52) 72-73.

${ }^{151}$ LE Strine, "One Fundamental Corporate Governance Question We Face: Can Corporations be Managed for the Long Term unless Their Powerful Electorates also Act and Think Long Term?" (2011) 66 The Business Lawyer 26.
} 


\section{FORTHECOMING}

were in fact finally served. ${ }^{152}$ Shareholders of the company included passive UK investors, who owned 28 per cent of the stock in September 2009, as well as US investors showing the same disinterest, who owned almost half of the company's shares. ${ }^{178}$ After Kraft's public announcement of its bid in September 2009, traditional shareholders of Cadbury started selling their shares, so that finally one-third of Cadbury's stock was held by hedge funds in January 2010. ${ }^{179}$ The outcome of the takeover was met with disapproval by Cadbury's second largest institutional investor, Legal \& General, which owned a 5 per cent stake in the company. It considered that the board should not have recommended the bid since the final price offered by Kraft did not "fully reflect the longterm value of the company". ${ }^{180}$ Franklin Mutual Advisers, a USbased investor that owned more than a 7 per cent stake in the company at the time, had indicated "absolutely no interest in accepting Kraft's offer". ${ }^{153}$ However, it should be noted that aiming to secure a mutual agreement on the merits of the bid from all shareholders would be difficult to achieve in light of the fact that each type of shareholder had different expectations from their investment and therefore a different stance toward the bid. ${ }^{154}$

The key question to be answered is how a focus on the long-term continuity of the firm can be kept separate from the short-term investment plans that certain shareholders, such as hedge funds, are likely to have. ${ }^{183}$ If it is the company's purpose to maintain "a longterm sustainable vision" despite investors coming in and out of the company on a frequent basis according to their own investment strategies, then it remains important for directors to be aware of the company's exact strategy and disclose it to other long-term investors

\footnotetext{
${ }^{152}$ Wiggins (n 38).

178 ibid.

179ibid. 180

ibid.
}

${ }^{153}$ Z Wood, "Kraft Set for Higher Cadbury Bid as Deadline Looms" The Guardian (18 January 2010). ${ }^{154}$ M Scott, "Short-Termism Requires Long-Term Vision” Financial Times (16 January 2011). 183 ibid. 
in the interim. ${ }^{155}$ The rise of hedge fund ownership in UK firms over the past decade in particular is admittedly a sound basis on which the rules need be revised. ${ }^{156}$ The practice of merger arbitrage having a negative impact on the quality of future UK deals can be highlighted, but at the same time questioned. In light of the fact that, as pointed out, 70 per cent of Cadbury's investors at the crucial decision period were in fact institutional investors, hedge funds' role in determining the fate of Cadbury has arguably been overestimated. ${ }^{157}$ Parallel to hedge funds' strategies, the myopic view of other institutional shareholders for short-term returns has also been criticised for being not only the cause for the increase in hedge fund turnover, ${ }^{158}$ but arguably the reason that improper or opportunistic bids succeed. Irrespective of the complementary framework regulating the investment strategies assumed by various shareholders, this section has highlighted that the type of investor deciding on the outcome of a bid is an important variable that has been overlooked by past scholarship and that, accordingly, may form the basis for reform of the rules.

\section{H. CONCLUSION}

The takeover of Cadbury by Kraft in 2010 pointed out, amongst other things, that, under the current legal framework, target directors are prompted to "selloff" the company under siege by recommending any price that significantly exceeds the company's trading price without considering the long-term implications of the takeover bid in their advice. ${ }^{159}$ However, as the present article has argued, this is not attributed to an error in the way in which directors

\footnotetext{
155 ibid. Note that disclosure must be made to all shareholders following the provisions of the Market Abuse Directive 2003/6/EC of the European Parliament and of the Council of 28 January 2003 on insider dealing and market manipulation [2003] OJ L96/16.

${ }^{156}$ A Wells, “Takeovers and Mergers. Are You a Cadbury's Fruit and Nut Case?” (2011) 32 Business Law Review 114.

${ }^{157}$ S Jones, "How the Hedge Fund Industry Influences Boardroom Battles" Financial Times (22 June 2010).

${ }^{158}$ See Strine (n 176) 10.

${ }^{159}$ See Webb (n 11); First Response Paper (n 11).
} 
carry out their legal duties but, rather, to a problematic legal framework. The present article has identified that the Code, common law and the Companies Act 2006 in fact fail to provide target directors with established guidelines that would assist them in their advisory role, and specifically in methodically drafting their opinion of a bid to target shareholders. The grey areas of law reported on are not the result of poor law drafting but, rather, the result of the regulator not reaching equilibrium between the conflicting aims of facilitating an open market for corporate control on the one hand and avoiding short-termism in corporate strategy on the other. The paper has argued that one of the regulatory means available to balance out these conflicting aims is to provide directors with clear-cut guidance on how to construct their advice. The general language used by the Code is positive insofar as it provides target directors with discretion as to how to observe their advisory role. However, as the case studied has shown, excess uncertainty as to how target directors should discharge their advisory responsibilities makes it necessary for the law to step in and provide guidance on this particular matter. Were the law to provide clarity on the matter, target directors would arguably be provided with a greater opportunity to reject bids which do not promote the long-term success of either the target or the bidding company. The paper proposes that the Code should include a list of factors that target directors are required to reflect on when deciding whether or not to recommend a deal, similar to the indicative list that section 172 of the Companies Act 2006 provides. Such guidance would allow target directors to point to the specific reasons for which a bid should be rejected or accepted, leaving the ultimate decision to shareholders. Clarifying to whom target directors owe their duties would also prompt directors to produce a tailored opinion and address both shareholders looking for an immediate or early realisation of their investment and shareholders with a long-term perspective, by pointing to the prospects flowing from the company's independent long-term continuity. The legal framework should also make clear that, where different types of consideration are being offered, target directors should separately 
evaluate each class of consideration and, where shareholders are given elections, advise on the choices to be made.

The paper has argued that, in order to facilitate an open market for corporate control and a long-term vision for UK firms, there is a need to acknowledge that the share price will not always reflect the true value of the firm and that the target director is in a position to correct this informational asymmetry through his advice towards shareholders. In considering the different variables that are likely to impact target directors' decision on whether or not to recommend a bid, the paper has referred to the differences between cash and paper offers, as well as the differences between different types of shareholders. As it is commonly accepted that takeover outcomes should not be arbitrary, the paper has advocated in favour of reform by addressing directors' advisory duties within the takeover context specifically, and setting out provisions in the Code and the Companies Act accordingly. 